\title{
Review on Growth and Yield of Rice (Oryza sativa L.) as Influenced by Spacing and Nutrient Management Practices
}

\author{
M. Kumar ${ }^{1 *}$, N. Pandey ${ }^{2}$, G.K. Shrivastava ${ }^{3}$, S.C. Mukherjee ${ }^{4}$ and R.R. Saxena ${ }^{5}$ \\ ${ }^{1}$ SGCARS, Jagdalpur, India \\ ${ }^{2}$ Department of Agronomy, Indira Gandhi Krishi Vishwavidyalaya Raipur, India \\ ${ }^{3}$ DSW, Indira Gandhi Krishi Vishwavidyalaya Raipur, India \\ ${ }^{4} S G C A R S$, Indira Gandhi Krishi Vishwavidyalaya Raipur, India \\ ${ }^{5} A D R, I G K V$, Indira Gandhi Krishi Vishwavidyalaya Raipur, India \\ *Corresponding author
}

A B S T R A C T

\begin{tabular}{|l|}
\hline Ke y w or d s \\
Rice, Spacing, \\
Nutrient \\
management
\end{tabular}

Rice plant population and nutrient management is the key for higher productivity. In due course of $\mathrm{PhD}$ work on a neglected red rice crop which is grown by tribal's peoples of bastar plateau since time immemorial. Very few literatures are available on package and practices of red rice. This study has gone through several research papers concern with plant geometry and nutrient management in rice crop. In climate change era the land races of rice are capable to mitigate the effect of changing environment, when the frequency and intensity of rainfall is unpredictable. The landraces maintained by farmers are endowed with tremendous genetic variability, as they are not subjected to subtle selection over a long period of time. While most high yielding varieties in Asia are colorless with long and slender grains, local rice varieties often exhibit tremendous morphological diversity. This aids in the adaptation of landraces to wide agro-ecological conditions. This rich variability of complex quantitative traits still remains unexploited. Land-races are also important genetic resources for resistance to pests and diseases; they provide "adaptability genes" for specific environmental conditions.

\section{Introduction}

The nitrogen, phosphorus and potassium are the major nutrient required by rice crop. Besides many micro nutrients one also needed for growth development and yield of rice. Rice plant requires an adequate supply of nutrients from various sources for optimal growth. These nutrients are supplied by indigenous sources such as soil minerals, soil organic matter, rice straw, manure, and water (rain, irrigation), but the amount supplied is usually insufficient to achieve high and sustainable yields. Fertilizers need to be applied to overcome the deficit between crop requirement and nutrient supply from the above-mentioned sources. The crop requirement of nutrients depends on variety and season. However, the full potential of improved nutrient management can only be reached with good crop management and selection of suitable varieties. An effective 
agronomic management is therefore necessary to exploit the yield potential of rice. Integrated nutrient management (INM) involving organic and inorganic sources of nutrient are very important in rice production. Many of our problems on declining productivity (increasing cost, declining yield) can be traced to improper and inefficient use of nutrients. Improper nutrient management has resulted in the nutrient imbalances in the soil with nutrients in excess while other nutrients depleted.

Through this, farmers can increase agricultural productivity and safeguard the environment as they efficiently use fertilizer. Searching rice cultivars or variety with high yield potential and quality under different levels of nutrient supplied and plant population are prime important in the present context of rice research. Diverse studies across different agro-ecosystems have shown importance of organic nutrient sources in improving crop yield and improving soil quality. Reference reported that response of rice to nutrient supply by organic and inorganic fertilizer is universal but may vary with locations, soil and fertilizer types. Similarly, crops have been reported to respond differently to different composts under similar soil fertility condition.

Effect of spacing on growth, yield attributes and yield of rice

Bridgit and Potty (2002) and Nayak et al., (2003) reported that higher yield in $30 \mathrm{~cm} \mathrm{x}$ $30 \mathrm{~cm}$ spacing was due to less competition among the plants for nutrients and moisture better aeration which encourages better root development. Productive tillers hill ${ }^{-1}$ was not affected significantly by seedling density. Obulamma et al., (2004) mentioned that spikelet's panicle ${ }^{-1}$ was significantly higher at wider spacing. Sterility percentage was observed to be significantly higher at closer spacing $(20 \mathrm{~cm} \times 10 \mathrm{~cm})$. Grain yield was not significantly affected by spacing. However, wider spacing of $20 \mathrm{~cm} \mathrm{x} 15 \mathrm{~cm}$ produced more grain yield compared to narrow spacing $(20 \mathrm{~cm} \times 10 \mathrm{~cm})$. The number of filled grains panicle $^{-1}$ was significantly higher with one seedling hill ${ }^{-1}$. This can be attributed to the significantly higher sterility percentage recorded at two seedlings hill ${ }^{-1}$.Frizzell et al., (2006) while comparing row widths for conventional varieties suggested that narrows rows may be preferable over wider rows. Islam et al., (2009) reported that thousand grain weights failed to show any significant variation with seedling density as it may be an attribute controlled by the genetic makeup of the variety. Salahuddin et al., (2010) studied that five levels of nitrogen $(0,50,100,150$, $\left.200 \mathrm{~kg} \mathrm{~N} \mathrm{ha}^{-1}\right)$ and three spacing's $(25 \mathrm{~cm} \mathrm{x}$ $20 \mathrm{~cm}, 25 \mathrm{~cm} \times 15 \mathrm{~cm}, 25 \mathrm{~cm} \times 10 \mathrm{~cm})$ and noted gradual increase in panicle length $(24.50 \mathrm{~cm})$, grains panicle ${ }^{-1}(110)$ and grain yield $\left(4.91 \mathrm{t} \mathrm{ha}^{-1}\right)$ were with the increase in nitrogen levels up to $150 \mathrm{~kg} \mathrm{ha}^{-1}$ and declined thereafter.

Thousand-grain weight was not significantly influenced by application of different levels of nitrogen. The maximum grain yield $(4.22 \mathrm{t}$ $\mathrm{ha}^{-1}$ ) was observed at the spacing $25 \mathrm{~cm} \times 10$ cm closely followed by $25 \mathrm{~cm} \times 15 \mathrm{~cm}(4.21 \mathrm{t}$ $\left.h^{-1}\right)$. Wider spacing $(25 \mathrm{~cm} \quad \mathrm{x} \quad 10 \mathrm{~cm})$ produced the tallest plant $(108.38 \mathrm{~cm})$, but significantly highest tillers hill (8.06) and grains panicle ${ }^{-1}$ was recorded from $(25 \mathrm{~cm} \mathrm{x}$ $20 \mathrm{~cm}$ ). Plant spacing had also no significant effect on 1000 grain weight. The interaction effects of nitrogen and plant spacing was significant in panicle length, grains panicle ${ }^{-1}$, and grain yield. The higher grain yield $(5.00 \mathrm{t}$ $\mathrm{ha}^{-1}$ ) was recorded from the treatment combination of $150 \mathrm{~kg} \mathrm{~N} \mathrm{ha}^{-1}$ with $25 \mathrm{~cm} \mathrm{x} 15$ $\mathrm{cm}$ spacing, but statistically identical to same $\mathrm{N}$ dose with other two spacing. Response of grain yield to added $\mathrm{N}$ was quadratic. The optimum doses were found to be $132 \mathrm{~kg} \mathrm{~N}$ 
$\mathrm{ha}^{-1}$ for $25 \mathrm{~cm} \times 20 \mathrm{~cm}, 119 \mathrm{~kg} \mathrm{~N} \mathrm{ha}^{-1}$ for 25 $\mathrm{cm}$, and $177 \mathrm{~kg} \mathrm{~N} \mathrm{ha}^{-1}$ for $25 \mathrm{~cm} \mathrm{x} 10 \mathrm{~cm}$ spacing, yielding 4.38, 4.63 and $4.75 \mathrm{t} \mathrm{ha}^{-1}$ respectively.

\section{Effect of inorganic nutrient on growth,} yield attributes and yield of rice

Barker et al., (1985) observed that the impact of increased fertilizer use on crop production has been large, but ever increasing cost of energy is an important constraint for increased use of inorganic fertilizer. Kumar and Prasad (2003) reported that application of $10 \mathrm{t} \mathrm{ha}{ }^{-1}$ FYM in rice-wheat system significantly increased $\mathrm{N}, \mathrm{P}$ and $\mathrm{K}$ content by 4.0, 7.8 and 7.6 percent as compared with no FYM. In rice straw $\mathrm{N}$ and $\mathrm{P}$ content remained unaffected with increase in fertilizer levels but $\mathrm{K}$ content was increased significantly with increased fertilizer dose from 0 to $100 \%$ RDF. Highest level of fertilizer (100\% RDF) produced highest $\mathrm{K}$ content in straw and was followed by $50 \%$ RDF. Significantly minimum $\mathrm{K}$ content in Straw was observed with no fertilization. Ahmad et al., (2005) reported that the increase in straw yield and harvest index at higher nutrient levels. Tripathi et al., (2013) mentioned that the better yield attributes and yield with the application of highest level of nutrients might be due to its key role in root development, energy translocation and metabolic process through which increased translocation of photosynthates towards sink development might have occurred. Hairmansis et al., (2010) reported that grain yield and straw yield were maximum at 150:75:75 $\mathrm{kg}$ NPK $\mathrm{ha}^{-1}$. This could be attributed to the positive and moderate direct effect of number of productive tillers and the strong direct effect of filled grains panicle ${ }^{-1}$ on grain yield. Significant improvement in dry matter accumulation of rice with increasing nutrition on account of better growth and development of the plant.
Effect of organic nutrients on growth, yield attribute and yield of rice

Mathew et al., (1993) also recorded increment in grain yield by application of FYM. Manjappa et al., (1994) found sustaining soil productivity; organic manures also improved nutrient use efficiency of the crop. Sharma (1994) noted that the grain and straw increased with the increased rate of FYM. Gill et al., (1994) reported that rice yields increased significantly with the increase in nitrogen levels up to $100 \mathrm{~kg} \mathrm{ha}^{-1}$. Rice yields still higher in 100 per cent application of N, P and $\mathrm{K}$ and in treatments with part of $\mathrm{N}$ supplied through various organic sources. Among all the treatments, application of 25 per cent and 50 per cent $\mathrm{N}$ through paddy straw gave significantly higher grain and straw yields, respectively. Ladha et al., (1996) noticed that application of organic sources of nutrients in rice crop showed beneficial effect on succeeding crop i.e. maize in the summer season. Though the green manures are good source nutrients, they cannot meet the total crop nutrient requirement in the present day agriculture water management alternatives and plant spacing optimum plant density per unit area is an important factor needed for realizing higher yields. Mhaske et al., (1997) noted higher plant height and number of tillers plant ${ }^{-1}$ with the application of FYM @ $12 \mathrm{t} \mathrm{ha}^{-1}$ compared to no FYM application. At CRRI, Cuttack, application of $10 \mathrm{t} \mathrm{FYM} \mathrm{ha}^{-1}$ increased the grain yield compared with no FYM, and the yield was similar to that obtained with 20 or $40 \mathrm{~kg} \mathrm{~N}^{-1}$ while, Ghosh and Sharma, (1999) noticed there was no significant difference in grain yield due to the application of $\mathrm{N}$-fertilizer in plots treated with FYM. Ayoub (1999) reported that use of organic matter to meet the nutrient requirement of crops would be an inevitable practice in years to come, particularly for resource poor farmers. Further, more ecological and environment concerns over the 
increased and indiscriminate use of inorganic fertilizers have made research on use of organic materials as a source of nutrients very necessary. Hossain and Singh (2002) revealed that the organic materials particularly farmyard manure and green manure have traditionally been used by rice farmers in preindustrial age. But the present day high yielding cultivars, which have higher nutrient requirements, the use of inorganic fertilizers has increased considerably leading to decline in the use of organic materials. Sharma and Sharma (2002) observed that the increase in organic carbon content in treatments with combination of both organic and in organic sources may be attributed to higher biomass addition to soil through crop residues. Tolanur and Badanur (2003) reported that FYM and green manure addition with inorganic fertilizers had the beneficial effect on increasing the available $\mathrm{P}$ status of soil. Mirza et al., (2005) reported that productive tillers were increased by the application of FYM but differences were not significant between 10 and $20 \mathrm{t} \mathrm{ha}^{-1}$ of FYM application. The increases in paddy yield due to application of 5,10 and $20 \mathrm{t}$ ha- 1 of FYM were $6.8 \%$, $24.4 \%$ and $37.6 \%$, respectively over control. Laxminarayana (2006) reported that the declining trend of available potassium among all the treatments may be attributed to crop removal due to continuous cropping. Singh et al., (2008) mentioned that lowering of organic carbon content of soil was common in control and in treatments with only inorganic fertilizers.This type of lowering of organic carbon content of soil may be due to its rapid mineralization resulting from intensive cropping and also as a result of attaining stable equilibrium with the changing soil crop environment. Singh et al., (2008) noted that organic sources have maintained relatively higher available potassium content. Yogananda et al., (2012) reported that transplanted rice responded positively with increasing level of FYM. The maximum average grain yield (4166 kg ha-1) and straw yield $\left(5212 \mathrm{~kg} \mathrm{ha}^{-1}\right)$ was observed with application of $12.5 \mathrm{t}$ FYM followed by $10 \mathrm{t}$ FYM equivalent (3918 and $4769 \mathrm{~kg} \mathrm{ha}^{-1}$, respectively) and found superior over all other treatments. Pandey (2012) and Rathod et al., (2012) the improvement in organic carbon, microbial population and physical properties of the soil may be the reason of the more crop productivity.

\section{Effect of integrated nutrient management on growth, yield attributes and yield of rice}

Santhy et al., (1998) observed that total uptake of $\mathrm{N}, \mathrm{P}$ and $\mathrm{K}$ increased progressively in the supply of NPK to the crops, because of higher availability of these nutrients. Application of NPK at $100 \%$ of optimum level along with FYM @ $10 \mathrm{t} \mathrm{ha}^{-1}$ increased nutrient uptake over the application of $100 \%$ optimum level of NPK alone. Pandey et al., (1999) reported that application of $10 \mathrm{t} \mathrm{FYM}$ $\mathrm{ha}^{-1}, 80 \mathrm{~kg} \mathrm{~N} \mathrm{ha}^{-1}$ along with $5 \mathrm{t} \mathrm{FYM} \mathrm{ha}{ }^{-1}$ and $40 \mathrm{~kg} \mathrm{~N}^{-1}$ were as effective as $120 \mathrm{~kg}$ $\mathrm{N} \mathrm{ha}{ }^{-1}$ for grain yield of scented rice cv. Madhuri and Pusa Basmati-1.Sarawgi and Sarawgi (2004a) found that higher level of nutrients (i.e. 50:50:40 kg NPK ha ${ }^{-1}+$ nitrogen blended with FYM) recorded significantly higher number of tillers plant ${ }^{-1}$, plant height, panicles plant $^{-1}$, length of panicle, number of filled grains panicle ${ }^{-1}$, filled grain weight, test weight and grain yield of tall and short slender scented rice varieties compared to lower level of nutrients (i.e. 25:40:30 $\mathrm{kg} \mathrm{NPK} \mathrm{ha}^{-1}$ ) with or without blending with FYM. At both level of nutrients, blending with FYM proved better in all growth, yield and yield attributing characters. It was also found that application of $10 \mathrm{t} \mathrm{FYM} \mathrm{ha}^{-1}$ (i.e. 45:20:40 kg NPK ha ${ }^{-1}$ ) did not show any positive effect on yield and yield attributes of short to medium slender rice varieties. Sarawgi and Sarawgi (2004b) revealed that higher level of nutrients (i.e. 
60:50:40 kg NPK ha ${ }^{-1}+\mathrm{N}$ blended with FYM) recorded significantly higher number of tillers plant ${ }^{-1}$ at maximum tillering stage, plant height, panicles plant ${ }^{-1}$, panicle length, panicle weight, test weight, filled grains as well as total number of grains panicle ${ }^{-1}$, grain and straw yield of semi tall and short to medium slender scented rice varieties followed by same level of nutrients blending and lower level of nutrients (40:40:30 kg NPK ha ${ }^{-1}$ ) with or without blending. Further, it was observed that there was no significant differences in between lower level of nutrient blended with FYM (40:40:30 kg NPK ha ${ }^{-1}+$ $\mathrm{N}$ blended with FYM) and higher level of nutrient without blending (60:50:40 kg NPK $\mathrm{ha}^{-1}$ ) for plant height, panicle length, test weight, number of filled grains as well as total number of grains panicle ${ }^{-1}$ and straw yield. It was also found that application of $10 \mathrm{t}$ FYM $\mathrm{ha}^{-1}$ (45:20:40 kg NPK ha ${ }^{-1}$ ) proved as good as higher level of nutrient (60:50:40 kg NPK $\mathrm{ha}^{-1}$ ) without blending. Pandey and Nandeha (2004) reported that application of chemical fertilizers@ 120:60:30 kg NPK ha ${ }^{-1}$ produced significantly higher grain yield of scented rice during both the years. However, the response of FYM alone was at par with all the chemical fertilizers. Singh and Tripathi (2005) reported that soil OC and available P content increased significantly due to organic farming practice compared the control as well as chemical fertilizer application. Khadayate et al., (2005) reported that the different organic and inorganic sources of nutrients, alone and in combinations, significantly influenced the rice yield, yield attributing parameters, content and uptake of nutrients (N P and $\mathrm{K}$ ) by rice. Among the different organic sources, FYM was recorded the highest yield. Sarawgi et al., (2006) revealed that the grain yield of scented rice varied significantly due to nutrient management. Higher level of nutrients (i.e. 60:50:40 kg N: $\mathrm{P}_{2} \mathrm{O}_{5}: \mathrm{K}_{2} \mathrm{O} \mathrm{ha}^{-1}+$ Nitrogen blended with FYM) recorded significantly higher grain yield of scented rice than rest of the nutrient management practices. Urkurkar et al., (2006) found highest yield sustainability and net return of rice and available $\mathrm{N}$ in soil under $50 \%$ of $\mathrm{N}$ substituted through green manure in conjunction with $50 \%$ of recommended NPK through inorganic fertilizers than $100 \%$ recommended dose of fertilizer and other combination of organic and inorganic sources over 16 years of study at Raipur. Roul et al., (2007) reported that the growth parameters like plant height, dry matter accumulation, root mass density as well as the physiological parameters like leaf area index, leaf area duration, light interception etc were significantly higher under $100 \%$ recommended dose of nitrogen blended with FYM at $3 \mathrm{t} \mathrm{ha}^{-1}$. Similar trend was also recorded with different yield attributes, grain and straw yield of rice. Satish et al., (2011) noticed significant increase in rice yield in treatments with paddy straw as source of nitrogen (25 to 50\%). Higher maize yield was observed in treatments with both organic and inorganic fertilizers in kharif followed by 100 per cent NPK in summer season, thus showing the beneficial effect of organic sources of nutrients on the succeeding crop and also improving the soil fertility levels. Gogoi (2011) reported that the application of $50 \%$ recommended dose of fertilizers (RDF) $+50 \% \mathrm{~N}$ (FYM) showed the lowest bulk density and the highest water holding capacity of soil. The above treatment was at par with 50\% N (inorganic) $+50 \% \mathrm{~N}$ $(\mathrm{FYM})+$ PK. However, effect of integrated nutrient management had a non-significant effect on $\mathrm{pH}$ of soil. At the end of the cropping sequence, significant soil organic carbon increased and higher available $\mathrm{N}$, $\mathrm{P}_{2} \mathrm{O}_{5}$ and $\mathrm{K}_{2} \mathrm{O}$ of soil were observed when $50 \%$ recommended dose of fertilizers (inorganic) substituted through 50\% N FYM (organic) over RDF and control. Ghosh et al., (2011) informed that on adoption of INM technology, the soil quality index (SQI) improved from 11.9 to $18.8 \%$ exhibiting 
highest in maize-potato-onion and lowest in paddy-wheat system. It is inferred that maizepotato-onion under limited irrigation treatment and maize-wheat + mustard under rainfed conditions are the best management options for maximizing water productivity, net return and soil quality. Upadhyay et al., (2011) noted that at the end of 5 cropping cycles, application of organic manures resulted in higher soil organic carbon, available $\mathrm{N}, \mathrm{P}$ and $\mathrm{K}$ than the chemical fertilizers. Maximum beneficial microorganisms were recorded under organic nutrient management (ONM) after completion of 5 crop cycles and the bulk density of soil was also lowered significantly in ONM. The $\mathrm{B}$ : $\mathrm{C}$ ratio was higher for chemical fertilizers in case of rice-durum wheat-green manuring (3.6) and rice-potato-okra (3.1) due to lesser cost of cultivation. Jahiruddin et al., (2012) stated that the integrated use of poultry manure or compost with fertilizers demonstrated about $25 \%$ yield increase over $100 \%$ fertilizer treatment. Positive residual effect of manure was observed in the following two rice crops. A separate field trial was made to evaluate the effect of INM with cow dung or poultry bio-slurry on potato crop. It revealed that bio-slurry had better effect on tuber yield compared to cow dung or poultry manure. This study indicates that integrated use of manure and fertilizers is a better practice for obtaining higher crop yield. Hussain et al., (2012) noted that the values of yield attributes viz., panicle length and number of spikelets panicle ${ }^{-1}$ were significantly higher with application of RFD + poultry manure@ $20 \mathrm{t} \mathrm{ha}^{-1}$, whereas grains panicle $^{-1}$ and panicles $\mathrm{m}^{-1}$ were significantly higher with application of FYM @ $20 \mathrm{t} \mathrm{ha}^{-1}+$ $75 \%$ recommended fertilizer dose. Nath et al., (2012) investigated the multifaceted effects of INM treatments that facilitated beneficial soil conditions were reflected in terms of significant increase in the grain yield of both rice $\left(3.87 \mathrm{t} \mathrm{ha}^{-1}\right)$ and toria $\left(1.04 \mathrm{t} \mathrm{ha}^{-1}\right)$ even over the $100 \%$ NPK. Dheri et al., (2013) studied five treatments $(100 \% \mathrm{~N}, 100 \% \mathrm{NP}$, $100 \%$ NPK, $100 \%$ NPK + FYM and the control). In the surface soil layer $(0-15 \mathrm{~cm})$, soil organic carbon (SOC) increased from the initial status of 2.42 to $3.26 \mathrm{~g} \mathrm{~kg}^{-1}$ in the control, which significantly increased with the application of $100 \%$ NPK $\left(4.11 \mathrm{~g} \mathrm{~kg}^{-1}\right)$ and $100 \% \mathrm{NPK}+\mathrm{FYM} \quad\left(4.55 \mathrm{~g} \mathrm{~kg}^{-1}\right)$. The ricewheat cropping even without any fertilization (control) contributed toward carbon sequestration $\left(1.94 \mathrm{MgC} \mathrm{ha}^{-1}\right)$ with soil organic carbon pools and carbon sequestration rate of $7.84 \mathrm{MgC} \mathrm{ha}^{-1}$ and $0.22 \mathrm{MgC} \mathrm{ha}^{-1} \mathrm{yr}^{-}$ ${ }^{1}$, respectively. Cao et al., (2013) reported that the integrated high-efficiency practice is effective in reducing $\mathrm{NH}_{3}$ loss and increasing rice yield and nitrogen use efficiency (NUE), and can be used for the sustainable development of rice production systems in the Taihu Lake region. Patel et al., (2013) from Varanasi reported that for securing higher yield and remuneration in rice - sugarcane (plant) - sugarcane (ratoon) cropping sequence, application of $25 \% \mathrm{~N}$ through FYM $+25 \% \mathrm{~N}$ through poultry manure $+50 \% \mathrm{~N}$ through inorganic fertilizer to the ricesugarcane (plant) - sugarcane (ratoon) cropping sequence not only gave net return and $\mathrm{B}$ : $\mathrm{C}$ ratio close to that obtained with application of $100 \%$ recommended dose of fertilizer as per soil test value or as per general state recommendation but also improved the soil health in terms of positive nutrient balance. Mohanty et al., (2013) reported from Odisha that application of $1 / 3$ rd recommended dose (RD) of $\mathrm{N}$ each through chemical fertilizer; FYM and Azolla registered the highest plant height and leaf area index in rice (Oryza sativa L.) as compared to other treatment combinations. Higher yield components (viz. number of panicles $\mathrm{m}^{-2}$, number of filled grains panicle ${ }^{-1}$ ) and grain and straw yield of rice were also achieved from the same treatment as compared to $100 \%$ recommended dose of 
fertilizer and control. Singh et al., (2013) observed that application of $75 \%$ of recommended NPK through inorganic + FYM @ $10 \mathrm{t} \mathrm{ha}^{-1}+\mathrm{BGA} @ 15 \mathrm{~kg} \mathrm{ha}^{-1}$ recorded significantly higher plant height, more no. of tillers/hill and yield. Tripathi et al., (2013) noted that the residual soil fertility improved considerably with the combined application of inorganic fertilizer and organics. It was concluded that integration of organics (Rhizobium, PSB \& FYM) with in organics led to $50 \%$ saving of inorganic fertilizer without scarifying the yield of sun hemprice cropping sequence and improved soil fertility status. Singh et al., (2013) noticed that INM resulted in higher plant height with longer leaves than chemical fertilizer alone. The seed quality parameters like germination rate and vigor index as well as $\mathrm{N}$ uptake and soil organic carbon content were higher in INM than those in chemical fertilizer alone.

\section{References}

Ahmed, S.A., Hussain, A., Ali, H. and Ahmad, A. 2005. Grain yield of transplanted rice (Oryza sativa L.) as influenced by plant density and nitrogen fertilization. Journal of Agriculture and Social Sciences, 1: 212-215.

Ayoub, A.T. 1999. Fertilizer and the Environment. Nutr. Cycl. Agroecosys, 55(2): 117-121.

Barker, R., Herdt, R.W. and Rose, B. 1985. The Rice Economy in Asia: Resources for the Future; Government Printing Office: Washington, D C.

Bridgit, A.J. and Potty, N.N. 2002. Influence of root characters on rice productivity in iron soils of Kerala, International. Rice Res., 27(1): 45-46.

Cao, Y., Tian, Y., Yin, B. and Zhu, Z. 2013. Assessment of ammonia volatilization from paddy fields under crop management practices aimed to increase grain yield and $\mathrm{N}$ efficiency. Field Crops Research, 147: 23-31.

Dheri, G., Kumar, B. and Singh, K. 2013. Carbon sequestration and soil carbon pools in a Rice-Wheat cropping system. Tillage Research, 128: 30-36.

Frizzell, D.L., Wilson,C.E., Norman, R.J., Slaton,N.A., Richards, A.L. and Runsick S.K. 2006. Influence of row spacing and seeding rate on rice grain yield. In:R.J. Norman, J.F. Ghosh, A. and Sharma, A.R. 1999. Effect of combined used organic manure and nitrogen fertilizer on the performance of rice under floodprone low land conditions. Journal of Agric. Sci., (Cambridge), 132(4): 461465.

Ghosh, B.N., Sharma, N.K. and Dadhwal, K.S . 2011. Integrated nutrient management and cropping systems impact on yield, water productivity and net return in valley soils of north-west Himalayas. Indian Journal of Soil Conservation, 39 (3):78-82.

Gill, M.S., Singh, T. and Ran, S.D. 1994. Integrated nutrient management in ricewheat cropping sequence in semi-arid tropics. Indian J. Agron., 39(4): 606608.

Gogoi, B. 2011. Soil properties and nutrients availability as affected by integrated nutrient management after rainfed cropping sequence. Indian Journal of Agricultural Research, 45(4): 36-39.

Hairmansis, A., Bambang, K., Supartopo, M. and Suwarno, T. 2010. Correlation analysis of agronomic characters and grain yield of rice for tidal swamp areas. Indonesian Journal of Agricultural Science, 11: 11-15.

Hossain, M. and Singh, V.P. 2002. Fertilizer use in Asian agriculture implications for sustaining food security and the environment. Nutr. Cycl. Agroecosy, 57(2):155-169. 
Hussain, A., Sheraz, S., Bhat, R.A., Rasool, F.A. and Raihana, H.K. 2012. Integrated nutrient management of Rice (Oryza sativa L.) under temperate conditions of Kashmir. Agricultural Science Digest, 32(1): 18-22.

Islam, M.S.H., Bhuiya, M.S.U., Gomosta, A.R., Sarkar, A.R. and Hussain, M.M. 2009. Evaluation of growth and yield of selected hybrid and inbred rice varieties grown in net-house during transplanted Aman season. Bangladesh Journal of Agricultural Research, 34:67-73.

Jahiruddin, M., Rahman, M.A., Haque, M.A., Rahman, M.M. and Islam, M.R. 2012. Integrated nutrient management for sustainable crop production in Bangladesh. Acta Horticulture, 958.

Khadayate, M.K., Sharma, G.K., Verma, S., Kumar, S. and Bajpayee, R.K. 2005. Effect of organic and inorganic sources of nutrients on rice yield, yield attributing parameters, content and uptake of nutrients in Alfisols of Chhattisgarh. Plant Archives, 5(2): 645648.

Kumar, V. and Prasad, B. 2003. Integrated nutrient management for rice-wheat system. J Res Birsa Agril Uni., 15: 2533.

Ladha, J.K., Kundu, D.K., Angelo, V., Coppenole, N.G., Peoples, M.B., Carangal, V.R. and Dart, P.J. 1996. Legume productivity and soil nitrogen dynamics in low land rice based cropping systems. Soil Science Society of American Journal, 60:183-192.

Laxminarayana, K. 2006. Effect of integrated use of inorganic and organic manures on soil properties, yield and nutrient uptake of rice in Ultisols of Mizoram. Indian Society of Soil Science, 54(1): 120-123.

Manjappa, K., Chandranath, H.T., Guggri, A.K. and Desai, B.K. 1994. Ways and means of increasing NUE in rice fields. Agricultural Reviews, 15(3-4): 195-204. Mathew, J., Varughese, K. and Pillai, G.R. 1993. Integrated nutrient management in a sandy loam soil on productivity and economics of rice. Oryza, 30: 26-29.

Mhaske, N.S., Borkar, S.L. and Rajgire, H.J. 1997. Effects of nitrogen levels on growth, yield and grain quality of rice. J. Soils and Crops, 7(1): 83-86.

Mirza, B.B., Zia, M.S., Szombathova, N. and Zaujec, A. 2005. Rehabilitation of Soils through Environmental Friendly Techonologies: Role of Sesbania and Farm Yard Manure. Agricultura Tropica Et Subtropica, 38(1): 11-17.

Mohanty, M., Nanda, S.S. and Barik, A.K. 2013. Effect of integrated nutrient management on growth, yield, nutrient uptake and economic of wet season Rice (Oryza Sativa L.) in Odisha. Indian Journal of Agricultural Sciences, 83(6): 22-24.

Nath, D.J., Ozah, B., Baruah, R., Barooah, R.C., Borah, D.K. and Gupta, M. 2012. Soil enzymes and microbial biomass carbon under Rice-Toria sequence as influenced by nutrient management. Indian Society of Soil Science, 60(1): 20-24.

Nayak, B.C., Dalei, B.B. and Choudhury, B.K. 2003. Response of hybrid rice to date of planting, spacing and seedling rate during wet season. Indian Journal of Agronomy, 48: 172-174.

Obulamma, U., Reddy, M.R. and Kumari, C.R. 2004. Effect of spacing and number of seedlings per hill on yield attributes and yield of hybrid rice. Madras Agriculture Journal, 91: 344347.

Pandey, A. 2012. Long term effect of organic and inorganic fertilizers on the distribution and transformation of $\mathrm{S}, \mathrm{Zn}$ and boron in calcareous soil. Ph.D. Thesis, Department of Soil Science, 
Rajendra Agriculture University, Pusa, Bihar.

Pandey, N., Sarawgi, A.K., Rastogi, N.K. and Tripathi, R.S. 1999. Effect of farm yard manure and chemical $\mathrm{N}$ fertilizer on grain yield and quality of scented rice (Oryza sativa L.) varieties. Indian Journal of Agricultural Science, 69(9): 621-623.

Pandey, T.D. and Nandeha, K.L. 2004. Response of scented rice (Oryza sativa L.) varieties to FYM and chemical fertilizers in Bastar Plateau. International Symposium on Rainfed Rice Ecosystems: Perspective and Potential. IGKV, Raipur, India. 11-13 $3^{\text {th }}$ Oct. pp. 105.

Patel, K.P., Thanki, J.D., Patel, D.D., Bafna, A.M., Arvadia, M.A. and Gami, R.C. 2013.

Integrated nutrient management in rice

-sugarcane (plant)-sugarcane (ratoon) cropping sequence. Indian Journal of Agronomy, 58(1): 9-14.

Rathod, D.D., Meena, N.C. and Patel, K.P. 2012. Evaluation of different zinc enriched organics as source of zinc under wheat maize (fodder) cropping sequence on zinc deficient typic Haplustepts. Journal of the Indian Society of Soil Science, 60: 50-55.

Roul, P.K., Sarawgi, S.K., Kumar, D. and Rout, D.P. 2007. Response of rice (Oryza sativa L.) to integrated nitrogen application in Inceptisols of Chhattisgarh. Oryza, 44(1): 39-43.

Salahuddin, K.M., Chowdhury, S.H., Munira, S., Islam, M.M. and Parvin, S. 2010. Response of nitrogen and plant spacing of transplanted Aman rice. Bangladesh Journal of Agricultural Research, 34: 279-285.

Santhy, P., Sankar, S.J., Muthuvel, P. and Selvi, D. 1998. Long term fertilizer experiments status of $\mathrm{N}, \mathrm{P}$ and $\mathrm{K}$ fractions in soil. J. Indian Society Soil Science, 46(3): 395-398.

Sarawgi, S.K. and Sarawgi, A.K. 2004a. Effect of blending of $\mathrm{N}$ with or without FYM on semi-dwarf, medium to long slender scented rice varieties in lowland alfisols of Chhattisgarh. In: International Symposium on Rainfed Rice Ecosystems: Perspective and Potential. IGKV, Raipur, India. 11-13 ${ }^{\text {th }}$ Oct., 2004. pp. 159-160.

Sarawgi, S.K. and Sarawgi, A.K. 2004b. Impact of integrated nutrient management on tall and short to medium slender scented rice varieties under lowland alfisols of Chhattisgarh plain. In: International Symposium on Rainfed Rice Ecosystems: Perspective and Potential. IGKV, Raipur, India. 11$13^{\text {th }}$ Oct., 2004. pp. 159.

Sarawgi, S.K., Purohit, K.K., Sarawgi, A.K. and Singh, A.P. 2006. Effect of nutrient management on semi dwarf, medium to long slender scented rice varieties in Alfisols of Chhattishgarh. Journal of Agricultural Issues, 11(1): 75-78.

Satish, A., Hugar, A.Y., Kusagur, N. and Chandrappa, H. 2011. Effect of integrated nutrient management on soil fertility status and productivity of RiceMaize sequence under permanent plot experiment. Indian Journal of Agricultural Research, 45(4): 32-34.

Sharma, G.D. 1994. Utilization of weed plants as organic manure under different methods of rice establishment. Indian $\mathrm{J}$. Agriculture Sciences, 64(3): 184- 186.

Sharma, S.K. and Sharma, S.N. 2002. Integrated nutrient management for sustainability of rice-wheat cropping system. Indian Journal of Agricultural Science, 72: 573-576.

Singh, R.K., Kumar, A. and Kaleem, M.J.S. 2013. Yield Maximization of hybrid rice (Oryza sativa L.) by 
integrated nutrient management. Journal of Progressive Agriculture, 4(1):18-22.

Singh, R.K., Singh, S.K. and Tarafdar, J.C. 2008. Influence of cropping sequence and nutrient management on soil organic carbon and nutrient status of Typic Rhodustalfs. Indian Soc. Soil Sci., 56: 174-181.

Singh, V.K., Tiwary, K.N., Gill, M.S., Sharma. S.K., Dwivedi, B. S., Shukla. A.K. and Mishra, P. 2008. Economic viability of site-specific nutrient management in rice -wheat cropping system. Better Crops, 92 (3): 28-30.

Singh, V.N. and Tripathi, B.N. 2005. Studies on the response of rice to nitrogen and zinc application methods in partially amended sodic soils. Farm Science Journal, 14: 19-21.

Singh, Y.V., Dhar, D.W. and Agarwal, B. 2013. Influence of organic nutrient management on Basmati rice (Oryza sativa L.) wheat (Triticum aestivum) green gram (Vigna radiata) cropping system. Indian Journal of Agronomy, 56(3): 169-175.

Tolanur, S.I. and Badanur, V.P. 2003. Effect of integrated use of organic manure, green manure and fertilizer nitrogen on sustaining productivity of rabi sorghum - chickpea system and fertility of a vertisol. J. Indian Soc. Soil Sci., 51: 4145 .
Tripathi, B.N., and Kumar, R. 2013. Effect of zinc and sulphur levels on rice in partially reclained typic Natrustalls sodic soil. Annals of Plant and Soil Research, 15: 27-30.

Tripathi, M.K., Majumdar, B., Bhandari, H.R., Chaudhary, B., Saha, A.R. and Mahapatra, $\quad$ B.S. 2013. Integrated nutrient management in sunn hemp-rice cropping sequence in Eastern Uttar Pradesh, India. Indian Journal of Agricultural Research, 47(3):22-25.

Upadhyay, V.B., Jain, V.M., Vishwakarma, S.K. and Kumar, A.K. 2011. Production potential, soil health, water productivity and economics of rice (Oryza sativa L.)-based cropping systems under different nutrient sources. Indian Journal of Agronomy, 56 (4): 28-32.

Urkurkar, J.S., Tiwari, A., Chitale, S. and Bajpai, R.K. 2006. Influence of long term use of inorganic and organic manures on soil fertility and sustainable productivity of rice -wheat in Inceptisols. Indian J. Agricultural Sciences, 80(3): 208-212.

Yogananda, S.B., Jagdeesh, B.R., Thimmegowda, S.K., and Vedashree, S.K. 2012. Effect of organic nutrient management practices on productivity of transplanting rice (Oryza sativa L.). Research J. Agriculture Sciences, 3(3): 650-653.

\section{How to cite this article:}

Kumar, M., N. Pandey, G.K. Shrivastava, S.C. Mukherjee and Saxena, R.R. 2018. Review on Growth and Yield of Rice (Oryza sativa L.) as Influenced by Spacing and Nutrient Management Practices. Int.J.Curr.Microbiol.App.Sci. 7(09): 52-61. doi: https://doi.org/10.20546/ijcmas.2018.709.007 